\title{
Interleukin-6 Family Cytokines
}

\author{
Stefan Rose-John \\ Institute of Biochemistry, Kiel University, Olshausenstrasse 40, Kiel, Germany \\ Correspondence: rosejohn@biochem.uni-kiel.de
}

The interleukin (IL)-6 family cytokines is a group of cytokines consisting of IL-6, IL-11, ciliary neurotrophic factor (CNTF), leukemia inhibitory factor (LIF), oncostatin M (OSM), cardiotrophin 1 (CT-1), cardiotrophin-like cytokine (CLC), and IL-27. They are grouped into one family because the receptor complex of each cytokine contains two (IL-6 and IL-11) or one molecule (all others cytokines) of the signaling receptor subunit gp130. IL-6 family cytokines have overlapping but also distinct biologic activities and are involved among others in the regulation of the hepatic acute phase reaction, in B-cell stimulation, in the regulation of the balance between regulatory and effector $\mathrm{T}$ cells, in metabolic regulation, and in many neural functions. Blockade of IL-6 family cytokines has been shown to be beneficial in autoimmune diseases, but bacterial infections and metabolic side effects have been observed. Recent advances in cytokine blockade might help to minimize such side effects during therapeutic blockade.

$\mathrm{C}$ ytokines are small $(15-20 \mathrm{kDa})$ and shortlived proteins important in autocrine, paracrine, and endocrine signaling. Cytokines coordinate the development and the activity of the immune system (Gandhi et al. 2016). Many cytokines belong to the four $\alpha$-helical class of mediators, which share a common up-up-downdown topology of the four helices. Furthermore, cytokines are grouped into families according to the structure and the specificity and composition of their receptor complexes. Cytokines bind to multimeric receptor complexes in which often one subunit is also found in the receptor complexes for other cytokines (Spangler et al. 2015). This is a reasonable classification because common receptor subunits imply similarity or even identity in intracellular signal transduction.

The class of four-helical cytokines consists of more than 35 interleukins and many mediators with trivial names such as growth hormone, prolactin, leptin, erythropoietin, throm- bopoietin, leukemia inhibitory factor (LIF), and oncostatin M (OSM). Moreover, all interferons and many colony-stimulating factors (CSFs) belong to this class of cytokines, which altogether contains far more than 60 members (Spangler et al. 2015).

Interleukin (IL)-6 family cytokines are defined as cytokines that use the common signaling receptor subunit glycoprotein $130 \mathrm{kDa}$ (gp130). Presently, eight cytokines fulfill this criterion although, as will be explained below, the group of IL-6 family cytokines is still expanding and the definition of gp130-containing complexes needs to be revised (Rose-John et al. 2015).

IL-6 family cytokines have been implicated in many functions, including B-cell stimulation and induction of the hepatic acute phase proteins. Moreover, metabolic functions and neurotrophic functions have been ascribed to this group of cytokines. Lately, an IL-6 receptor (IL-6R)-neutralizing monoclonal antibody (tocilizumab) has

Editors: Warren J. Leonard, and Robert D. Schreiber

Additional Perspectives on Cytokines available at www.cshperspectives.org

Copyright (C) 2018 Cold Spring Harbor Laboratory Press; all rights reserved; doi: 10.1101/cshperspect.a028415

Cite this article as Cold Spring Harb Perspect Biol 2018;10:a028415 
been approved in more than 100 countries for the treatment of autoimmune diseases (Tanaka et al. 2014), and blockade of IL-6 activity was observed to be at least as efficient as the blockade of tumor necrosis factor $\alpha$ in patients with rheumatoid arthritis (Gabay et al. 2013).

This review covers the identification and complementary DNA (cDNA) cloning of IL-6 family cytokines, the identification of their cognate receptors, and the recognition that these cytokines form a large family of mediators, which are involved in the coordination of the immune system but also in many other physiologic functions as well.

\section{CLONING OF IL-6, IL-6R, AND gp130: THE IL-6R COMPLEX}

When the cDNA coding for B-cell stimulatory factor 2 (BSF-2) was cloned in 1986 by the Kishimoto group, the comparison of its protein sequence with the protein sequences of IL-1, IL2 , IL-4, interferon $\gamma($ IFN- $\gamma)$, granulocyte macrophage colony-stimulating factor (GM-CSF), and granulocyte colony-stimulating factor (GCSF) yielded only some faint similarities with G-CSF (Hirano et al. 1986). It became, however, immediately clear from the cDNA sequence that BSF-2 was identical to several other proteins with completely different biologic activities ( Table 1), indicating that the activity of the newly cloned BSF-2 was not restricted to the immune system. In December 1988, a group of 19 leading scientists in the field, including Dr. Kishimoto, agreed to refer to the protein as IL-6 (The New York Academy of Sciences Conference 1988).

No structural or functional information on IL-6 or the IL-6R complex was available until, in 1988, the Kishimoto group cloned the

Table 1. Synonyms of interleukin- 6 as evidenced on complementary DNA (cDNA) cloning of B-cell stimulatory factor 2 (BSF-2)

B-cell stimulatory factor-2 (Hirano et al. 1986)

Hepatocyte-stimulating factor (Gauldie et al. 1987)

Hybridoma-plasmacytoma growth factor

(Brakenhoff et al. 1987)

Interferon $\beta_{2}$ (Zilberstein et al. 1986)

$26 \mathrm{kDa}$ protein (Haegeman et al. 1986)
cDNA coding for the human IL-6R (Yamasaki et al. 1988). The receptor belonged to the immunoglobulin (Ig) superfamily but the cytoplasmic portion lacked a domain with discernible enzymatic activity, thus failing to provide any clue regarding the mechanism of signal transduction induced by IL-6. Figure 1 shows how IL-6 and IL-6R were seen during these early days of the cytokine field when there was no information on the structure of these molecules.

Because cytokines show very little homology at the protein level, it was not clear at the time that cytokines share common features and actually belong to a common protein family. At this time, a seminal article was published by Bazan (1990), who hypothesized that cytokines such as growth hormone, prolactin, IL-6, G-CSF, and erythropoietin belong to the protein family of four-helical cytokines. Bazan stated that lymphokines, interleukins, CSFs, growth hormones, and interferons, which he collectively designated as cytokines, display no (or at best fragmentary) similarities in amino acid sequence. All these proteins, however, were predicted or had been shown to be rich in $\alpha$-helices. Based on the then already-published X-ray structure of G-CSF (Abdel-Meguid et al. 1987) and the high predicted helical content of growth hormone, prolactin, IL-6, G-CSF, and erythropoietin, Bazan suggested a four-helical tertiary fold for cytokines, an idea that he also backed by the conserved gene exon/intron boundaries flanking the helices and by conserved disulfide bridge patterns (Bazan 1990). Based on his model, Bazan even detected that the protein topology in the then-published X-ray structure of IL-2 was incorrect and needed correction (Bazan 1992). Now we know that all cytokines of the IL-6 family, but also essentially all other cytokines, share the four-helices with an up-updown-down topology (Fig. 1). It was recognized that, instead of showing clear sequence homology, cytokines are characterized by a high structural homology (Spangler et al. 2015). Such structural homology extends to cytokine receptors, which all belong to the Ig superfamily and which contain a cytokine-binding module consisting of tandem fibronectin III domains where the amino-terminal domain contains a set of 

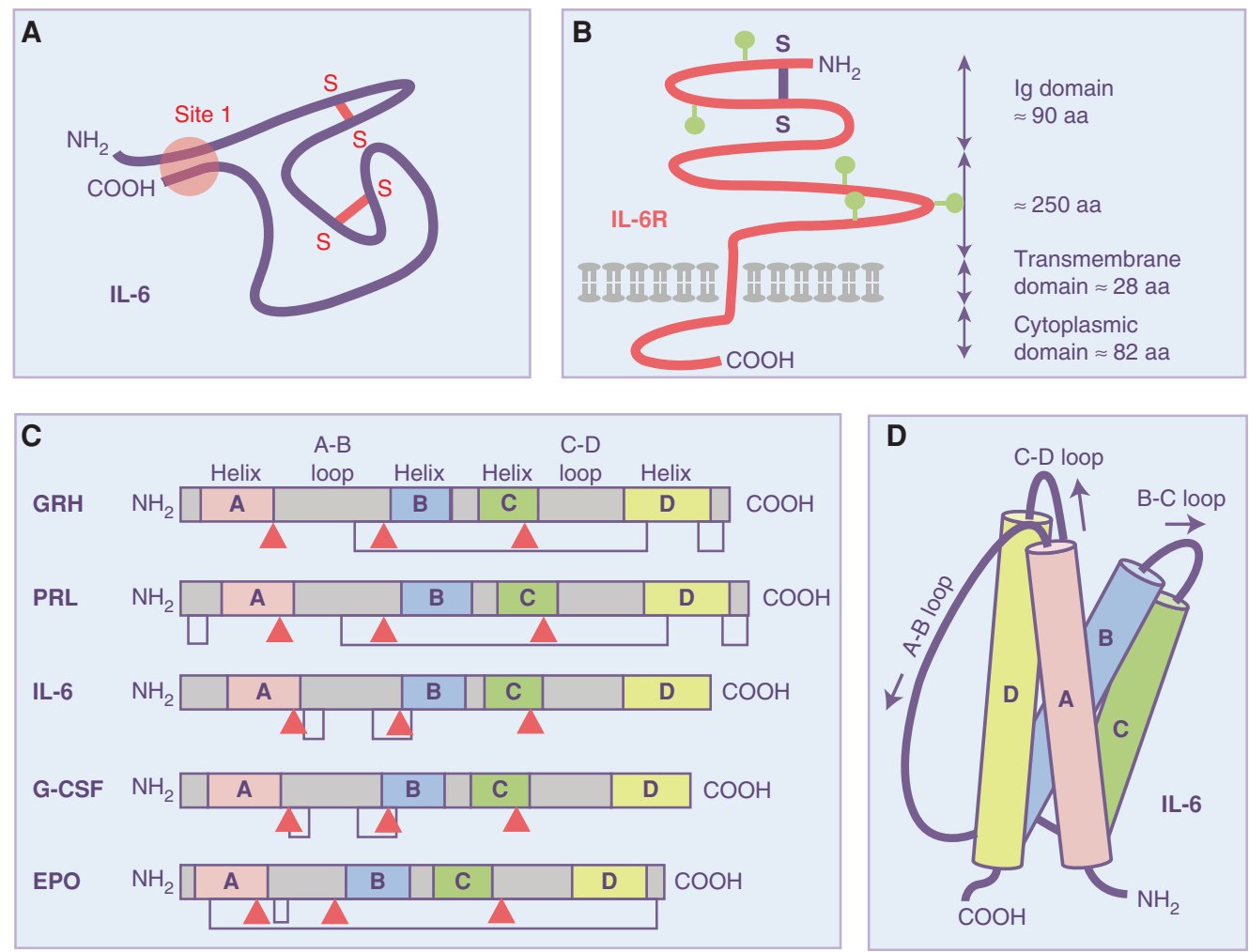

Figure 1. Recognition of interleukin-6 (IL-6) as a four-helical cytokine with up-up-down-down topology. $(A)$ IL-6 was functionally characterized by sets of monoclonal antibodies and it was stated that the $\mathrm{NH}_{2}$ terminus and the $\mathrm{COOH}$ terminus must be in close proximity in the biologic active IL-6 protein (Brakenhoff et al. 1990). Hypothesized disulfide bridges are indicated in red. $(B)$ When the complementary DNA (cDNA) coding for the IL-6 receptor (IL-6R) was cloned, no details about structure or function were available and only a schematic model of the IL-6R as a member of the immunoglobulin (Ig) superfamily could be envisioned (Hirano et al. 1989). A single hypothesized disulfide bridge is shown in blue. Postulated $N$-glycosylation sites are shown in green. (C) It was recognized by Bazan (1990) that, although growth hormone (GRH), prolactin (PRL), IL-6, granulocyte colony-stimulating factor (G-CSF), and erythropoietin (EPO) (Bazan 1990) display no (or at best fragmentary) similarities in amino acid sequence, they share exon-intron boundaries at predicted secondary structure elements (red arrowheads) and predicted disulfide bridges. Based on the known three-dimensional structure of G-CSF (Abdel-Meguid et al. 1987), Bazan postulated that GRH, PRL, IL-6, G-CSF, and EPO formed a structurally related family of cytokines. $(D)$ Model of the IL-6 as a four-helical cytokine with up-up-downdown topology (Bazan 1990).

four conserved cysteines and the membrane proximal domain contains a tryptophan-serine-X-tryptophan-serine motif (Spangler et al. 2015).

In 1990, the Kishimoto group cloned the cDNA coding for a $130 \mathrm{kDa}$ glycoprotein (gp130) (Hibi et al. 1990), which acted as a signal-transducing coreceptor for IL-6. The gp130 protein is expressed on all cells of the human body (Hibi et al. 1990; Oberg et al.
2006). It turned out that IL-6 signaling required both IL-6R and gp130. Only when IL-6 bound to the IL-6R, this complex bound to gp130, induced dimerization of gp130 and induced intracellular signaling (Fig. 2) (Taga et al. 1989; Hibi et al. 1990). Interestingly, the cytoplasmic portion of IL-6R was not needed for IL-6 signaling and, curiously, a truncated IL-6R lacking cytoplasmic and transmembrane domain in the presence of IL-6 was still able to bind to and 
S. Rose-John

activate gp130 (Taga et al. 1989; Hibi et al. 1990). Remarkably, it was shown that neither IL-6 nor IL-6R alone have a measurable affinity for gp130. Only the complex of IL-6 and IL-6R can bind to and activate gp130 (Taga et al. 1989; Hibi et al. 1990). This characteristic of the IL-6 system has important consequences for the therapeutic inhibition of IL-6 responses (see below).

Subsequently, the X-ray structure of the complex of IL-6, IL-6R, and gp130 was solved by the Garcia group and revealed a hexameric assembly of two molecules of IL-6, IL-6R, and gp130, which was proposed to serve as a blueprint of the other IL-6 family cytokines (Boulanger et al. 2003). The entire complex of IL-6,
IL-6R, gp130, and Janus kinase 1 (JAK1) has been reconstituted by electron microscopy imaging (Lupardus et al. 2011). The structural understanding of cytokine binding and activation of receptor complexes has recently made it possible to generate modified cytokines with altered (agonistic and antagonistic) properties (Spangler et al. 2015).

During the 1990s, intracellular signaling induced by activated gp130 was recognized to be mainly mediated by JAKs constitutively associated with the cytoplasmic portion of gp130, which led to the recruitment and activation of signal transducers and activators of transcription (STATs), which on phosphorylation by JAKs dimerize and translocate into the nucleus

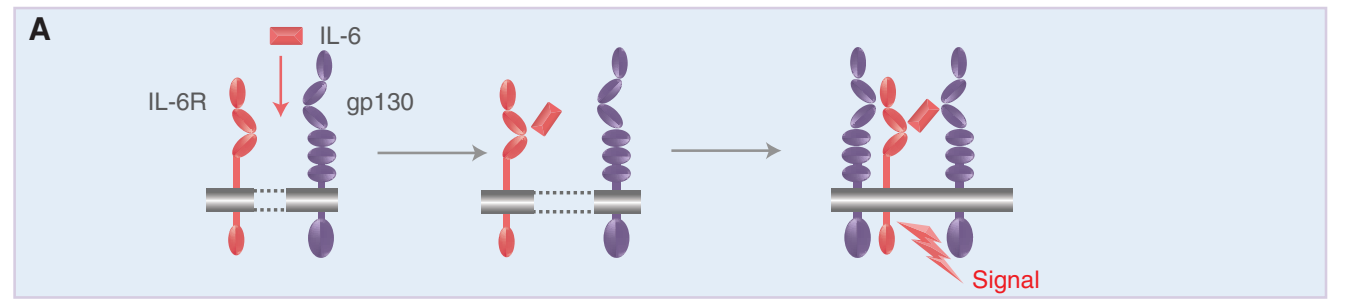

B
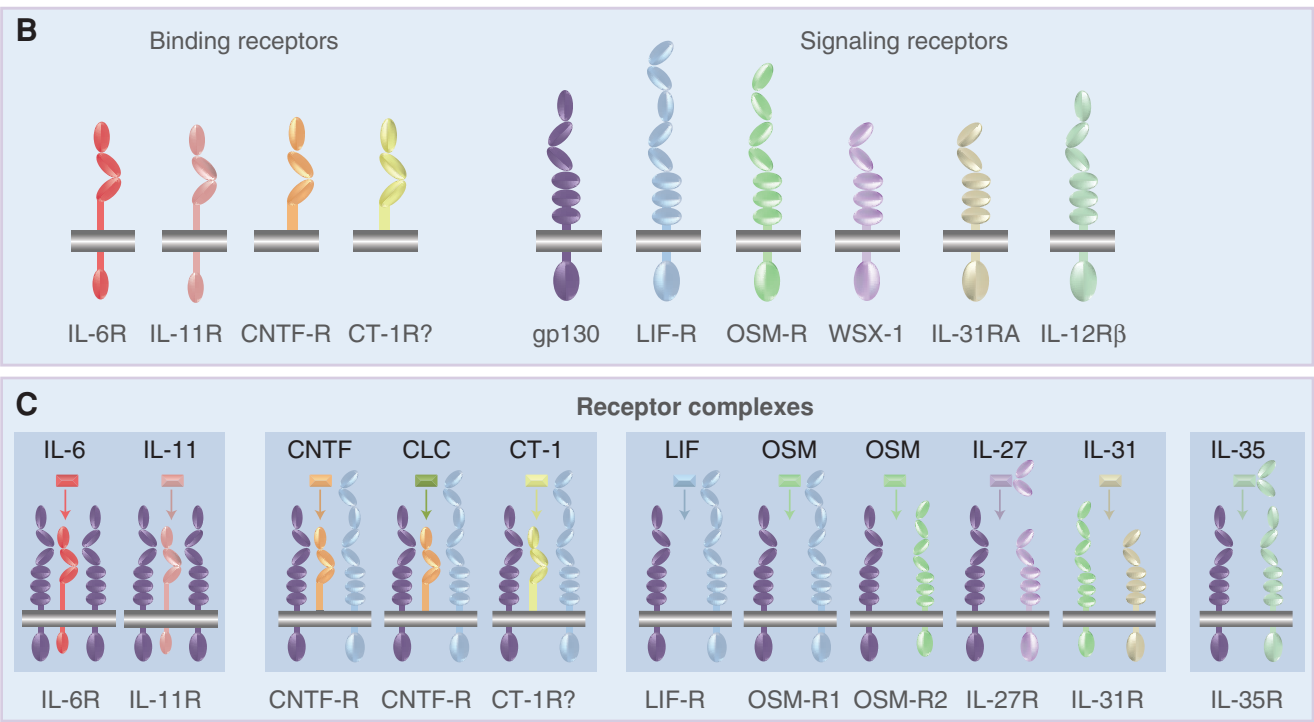

Figure 2. Molecular set-up of the interleukin-6 receptor (IL-6R) complex and comparison with other receptor complexes of IL-6 family cytokines. (A) IL-6 (red) binds to the membrane-bound IL-6R (red) and the complex of IL-6 and IL-6R associate with gp130 (lilac), which dimerizes and initiates signaling. (B) The IL-6 family cytokines act via four different ligand-binding receptors (left) and six different signaling receptors (right). $(C)$ Assembly of the receptor complexes of the IL-6 family cytokines. CNTF, Ciliary neurotrophic factor; CLC, cardiotrophin-like cytokine; CT-1, cardiotrophin 1; LIF, leukemia inhibitory factor; OSM, oncostatin M. 
to act as transcription factors (Levy and Darnell 2002). Thereby, gp130 signaling showed striking similarities with interferon signaling via JAKs and STATs (Lutticken et al. 1994). In the case of gp130, the main Janus kinase is JAK1 and the major signal transducer and activator of transcription is STAT3 (Schaper and RoseJohn 2015). Interferon and cytokine signaling via JAKs and STATs is discussed in Stark et al. (2017).

\section{gp130 IS A PLEIOTROPIC SIGNALING RECEPTOR: EMERGENCE OF A CYTOKINE FAMILY}

Shortly after the cloning of the IL- 6 cDNA, several additional cytokine cDNAs were molecularly cloned, including IL-11 (Paul et al. 1990), LIF (Gearing et al. 1987), ciliary neurotrophic factor (CNTF) (Lin et al. 1989; Stockli et al. 1989), OSM (Malik et al. 1989), and cardiotrophin 1 (CT-1) (Pennica et al. 1995). All of these cytokines showed similar but also distinct biologic activities, which could be explained by the fact that the receptor complexes of each of these cytokines contained gp130 (Gearing et al. 1992). All cytokines that use gp130 as a receptor subunit were referred to as IL-6 family cytokines or gp130 cytokines (Jones and Rose-John 2002; Jones et al. 2011). As detailed in Figure 2, the second signaling receptor in the case of CNTF, LIF, CT-1, and cardiotrophin-like cytokine (CLC) is the LIF receptor (LIF-R), a protein structurally related to gp130 (Gearing et al. 1991). OSM can alternatively bind to a heterodimer of gp130 and LIF-R or of gp130 and OSM receptor (OSM-R) (Mosley et al. 1996; Hermanns 2015). The dimeric cytokine IL-27 binds to a heterodimer of gp130 and WSX-1 (Aparicio-Siegmund and Garbers 2015). The signal transduction of all of these receptor complexes is similar, although subtle differences exist (Schaper and Rose-John 2015).

Cytokine specificity is brought about by the unique cell-surface expression of the receptor subunits. No natural cytokine can activate gp130 in the absence of other receptor subunits. Gp130 is the only receptor subunit that is expressed on all cells of the body, whereas all other receptor subunits show a more restricted expression pattern. It follows that the expression of these second receptor subunits determines whether a given cell will be able to respond to a given cytokine (Jones and Rose-John 2002; Jones et al. 2011).

Interestingly, the IL-6 family cytokines IL-6, IL-11, CNTF, CLC, and possibly CT-1 (Pennica et al. 1996) bind to specific cytokine-binding receptors, which are not signaling competent but rather present their ligand to the homodimeric or heterodimeric gp130-containing receptor complex. In contrast, the IL-6 family cytokines LIF, OSM, IL-27, and IL-31 directly interact with the two signaling receptor subunits without the help of a ligand-binding receptor subunit (Fig. 2). As will be explained below, the presence of nonsignaling receptor subunits enables a type of signaling that is not possible for cytokines without such specific receptors.

\section{IL-6 TRANS-SIGNALING VIA SOLUBLE RECEPTORS: A NEW PARADIGM NOT FOR IL-6 AND OTHER CYTOKINES AS WELL}

In the early 1990s, it was found that the IL-6R was efficiently cleaved from the cell surface by a then-unknown protease (Mullberg et al. $1992,1993)$. With the help of pulse-chase experiments, it was shown that IL-6R cleavage was complete after $24 \mathrm{~h}$ but could be drastically stimulated on stimulation of protein kinase $\mathrm{C}$ with the phorbol ester, PMA. Around the same time, a human messenger RNA (mRNA) species coding for an IL-6R devoid of a transmembrane domain was isolated (Lust et al. 1992). This mRNA originated from alternative splicing of the gene encoding IL-6R. In the mouse, no alternative splicing of the IL-6R mRNA was detected (Schumacher et al. 2015). Interestingly, it was shown that the soluble IL-6R (sIL-6R) cleaved from one cell, in the presence of IL-6, could stimulate cells, which did not express IL$6 \mathrm{R}$ and therefore were completely unresponsive to IL-6 (Mackiewicz et al. 1992). This process was called "trans-signaling" and it was speculated that this type of signaling via a soluble receptor contributed significantly to the biology of IL- 6 because it dramatically enlarged the spec- 
trum of target cells for IL-6 (Fig. 3A) (RoseJohn and Heinrich 1994).

The new paradigm of IL-6 trans-signaling was initially met with some skepticism in the scientific community because soluble receptors were assumed to act as antagonists by competing for their cognate ligands with membrane-bound receptors. This made it necessary to generate molecular tools to convincingly demonstrate the existence of trans-signaling not only in vitro but also in vivo.

The first tool we designed was "hyper-IL-6" (Fig. 3A), a protein in which IL-6 and sIL-6R are covalently connected by a flexible peptide linker
(Fischer et al. 1997). Comparing the response of many cells to IL- 6 and hyper-IL-6 allowed us to show that many cells, including hematopoietic stem cells (Fischer et al. 1997; Audet et al. 2001), embryonic stem cells (Viswanathan et al. 2002; Humphrey et al. 2004), and smooth muscle cells (Klouche et al. 1999), required sIL-6R for their response to IL-6. Moreover, we could show that efficient liver regeneration required IL-6 in combination with sIL-6R (Galun et al. 2000; Peters et al. 2000). Although the use of hyperIL- 6 showed the potential of IL- 6 trans-signaling, it did not prove that IL-6 trans-signaling actually occurred in vivo.

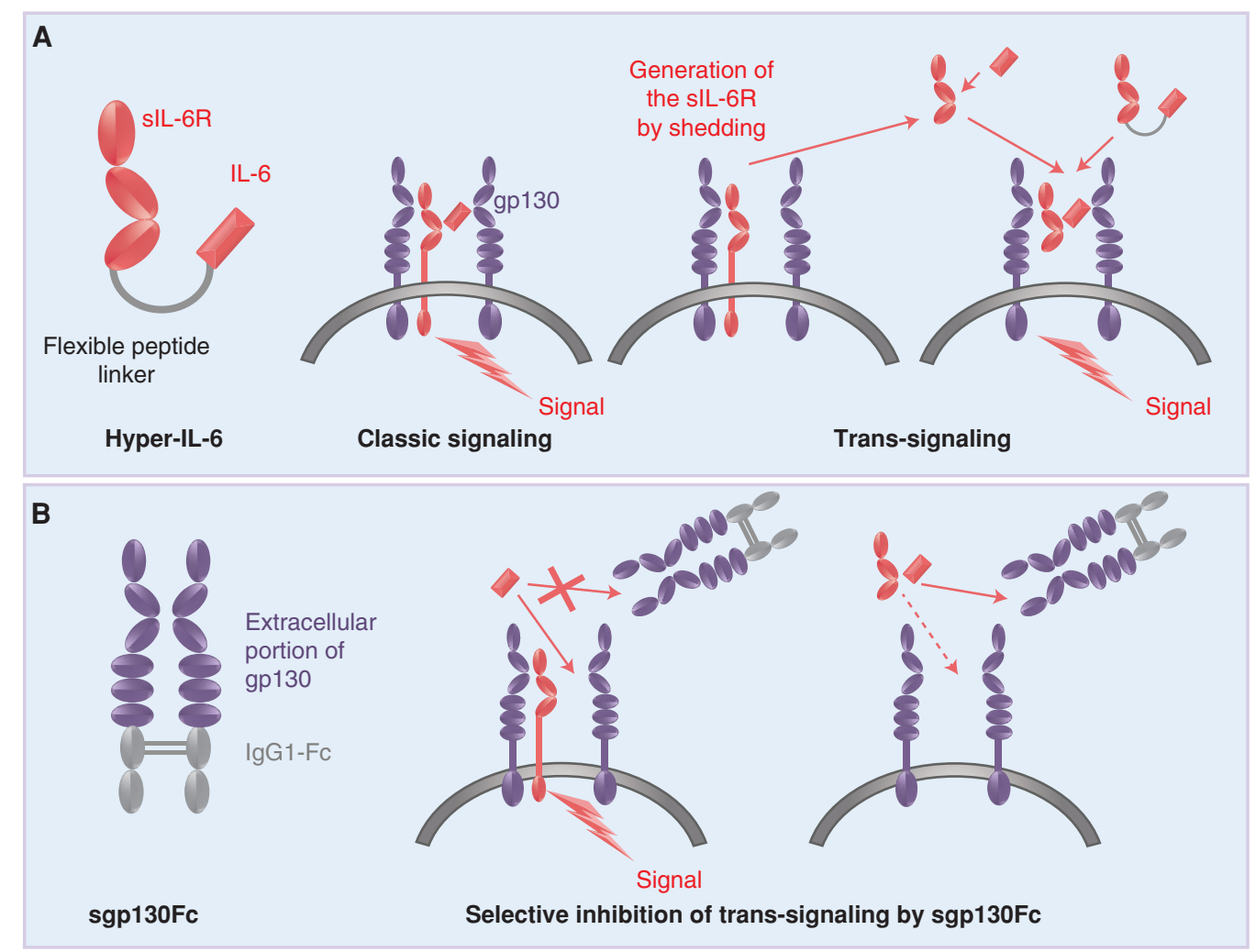

Figure 3. Molecular tools for the analysis of interleukin-6 (IL-6) trans-signaling. (A) IL-6 cannot only bind to the membrane-bound IL-6 receptor (IL-6R) (classic signaling) but also to a soluble IL-6R (sIL-6R), which can be generated by limited proteolysis via ADAM proteases. Cells, which express gp 130 but no IL-6R, are not responsive to IL- 6 but can be stimulated by the complex of IL- 6 and sIL-6R (trans-signaling). IL-6 trans-signaling can be mimicked by the designer cytokine hyper-IL-6 (left) in which IL-6 and sIL-6R are covalently connected by a flexible peptide linker. $(B)$ In the sgp130Fc protein, the extracellular portion of gp130 is fused to the constant portion of a human immunoglobulin $\mathrm{G}$ ( $\operatorname{IgG}) 1$ antibody leading to dimerization by disulfide bridges. Since gp130 has no measurable affinity for IL-6 but binds the IL-6/sIL-6R complex with high affinity, sgp130Fc selectively blocks IL-6 trans-signaling without affecting IL-6 classic signaling via the membrane-bound IL-6R. 
A second protein we generated consisted of the entire extracellular portion of gp130, which were dimerized using the Fc portion of human immunoglobulin G (IgG)1 antibodies, resulting in the protein sgp130Fc (Fig. 3B). Because IL-6 shows no measurable affinity to gp130, sgp 130Fc did not affect IL-6 signaling via the membrane-bound IL-6R (classic signaling), but it efficiently blocked IL-6 trans-signaling (Jostock et al. 2001). Thus, sgp130Fc is a molecular tool to distinguish between IL-6 classicand trans-signaling (Fig. 3B). In many animal models of human inflammatory or inflammation-associated cancer diseases, we side-by-side tested the consequences of global IL- 6 blockade with the help of neutralizing antibodies versus specific IL-6 trans-signaling blockade with sgp130Fc. In addition, many models were performed in $\mathrm{Il6}^{-/}$mice and in mice expressing the sgp130Fc as a transgene (Rabe et al. 2008). In all cases, the blockade of IL-6 trans-signaling was sufficient to block/inhibit the inflammatory state (Table 2 ).

Global blockade of IL-6 in patients leads to an increased susceptibility to bacterial infections (Selmi et al. 2015) as well as to an increase in serum cholesterol, serum triglycerides, and weight gain (Febbraio et al. 2010). Strikingly, selective blockade of IL-6 trans-signaling did not compromise host defense to mycobacteria (Sodenkamp et al. 2012), although infection was lethal in $I l 6^{-/-}$mice (Ladel et al. 1997). Listeria infection of mice was aggravated on global blockade of IL-6, whereas selective block- ade of IL- 6 trans-signaling by sgp 130Fc did not affect the defense of the body against this infection (Hoge et al. 2013). In mice fed a high-fat diet, selective blockade of IL-6 trans-signaling prevented the inflammatory infiltration of macrophages into adipose tissue (Kraakman et al. 2015) without leading to increased insulin resistance or decreased glucose tolerance, which had been observed in IL- $6^{-/}$mice (Matthews et al. 2010; Wunderlich et al. 2010). These data indicated that IL-6 signaling via the membranebound IL-6R but not via the sIL-6R are responsible for the metabolic side effects seen in patients after global IL-6 blockade with tocilizumab (Febbraio et al. 2010). Furthermore, comparison of global blockade of IL- 6 with selective blockade of IL-6 trans-signaling by sgp130Fc showed that IL-6 via the membranebound IL-6R shows regenerative activity in the intestine (Grivennikov et al. 2009), in the kidney (Luig et al. 2015), and in the pancreas (Zhang et al. 2013).

These accumulated data indicated that the proinflammatory activities of the cytokine IL-6 seem to depend mainly on trans-signaling via the sIL-6R, whereas the anti-inflammatory activities of the cytokine are mediated via the membrane-bound IL-6 (Fig. 4) (Jones et al. 2011; Calabrese and Rose-John 2014; SchmidtArras and Rose-John 2016). Furthermore, the sgp130Fc protein has been further developed and has passed clinical phase I trials with no adverse effects. Phase II clinical trials with inflammatory bowel disease patients began in 2016 .

Table 2. Efficacy of sgp130Fc-mediated blockade of interleukin-6 (IL-6) trans-signaling in preclinical models of inflammation and inflammation-associated cancer

\begin{tabular}{|c|c|c|}
\hline $\begin{array}{l}\text { Intestinal inflammation (Atreya et al. } \\
\text { 2000; Mitsuyama et al. 2006) }\end{array}$ & $\begin{array}{l}\text { Pancreatic cancer (Lesina et al. } \\
\text { 2011) }\end{array}$ & $\begin{array}{l}\text { Ovarian hyperstimulation (Wei } \\
\text { et al. 2013) }\end{array}$ \\
\hline $\begin{array}{l}\text { Rheumatoid arthritis (Nowell et al. } \\
\text { 2003, 2009; Richards et al. 2006) }\end{array}$ & $\begin{array}{l}\text { Acute inflammation (Chalaris } \\
\text { et al. 2007; Rabe et al. 2008) }\end{array}$ & $\begin{array}{l}\text { Lupus erythematosus (Tsantikos } \\
\text { et al. 2013) }\end{array}$ \\
\hline Asthma (Doganci et al. 2005) & $\begin{array}{l}\text { Sepsis (Barkhausen et al. 2011; } \\
\text { Greenhill et al. 2011) }\end{array}$ & $\begin{array}{l}\text { Nephrotoxic nephritis (Luig et al. } \\
\text { 2015; Braun et al. 2016) }\end{array}$ \\
\hline $\begin{array}{l}\text { Colon cancer (Grivennikov et al. 2009; } \\
\text { Matsumoto et al. 2010) }\end{array}$ & $\begin{array}{l}\text { Arterosclerosis (Schuett et al. } \\
\text { 2012) }\end{array}$ & Lung cancer (Brooks et al. 2016) \\
\hline $\begin{array}{l}\text { Ovarian cancer (Greenhill et al. 2011; } \\
\text { Lo et al. 2011) }\end{array}$ & $\begin{array}{l}\text { Pancreatitis-lung failure (Zhang } \\
\text { et al. 2013) }\end{array}$ & $\begin{array}{l}\text { Lung emphysema (Ruwanpura } \\
\text { et al. 2016) }\end{array}$ \\
\hline
\end{tabular}


S. Rose-John

\section{THE EXPANDING IL-6 FAMILY OF CYTOKINES}

As shown in Fig. 2, there are seven four-helical cytokines of the IL-6 family (IL-6, IL-11, LIF, OSM, CNTF, CT-1, and CLC), which bind to receptor complexes containing gp130. Additionally, IL-27 is a heterodimeric cytokine consisting of the four-helical protein p28 and a soluble cytokine receptor named EBI3, which is an Epstein-Barr virus-induced gene (Aparicio-Siegmund and Garbers 2015). EBI3 is also part of the heterodimeric cytokine IL-35, in which it forms a complex with p35, the fourhelical subunit of the heterodimeric cytokine IL-12. IL-35 interacts with different receptor complexes, which can be composed of gp130 and the $\beta$ subunit of the IL-12R, a homodimer of gp130, a homodimer of the $\beta$ subunit of the IL-12R or of the IL-27-specific receptor subunit WSX-1 complexed with the $\beta$ subunit of the IL-
12R (Egwuagu et al. 2015). The biology of the emerging family of IL-12 type cytokines is discussed in Yan et al. (2017). A cytokine related to the IL-6 cytokine family is the four-helical cytokine IL-31 (Fig. 2), which binds to a receptor complex formed by the OSM-R and the IL31RA (Dillon et al. 2004). Because the receptor complex for the cytokine does not contain gp130, IL-31 is not formally part of the IL-6 cytokine family, but it is highly IL-6-family-related because it interacts with a gp130 family receptor (Hermanns 2015).

\section{PLASTICITY OF THE IL-6 FAMILY OF CYTOKINES}

The IL-6R was believed to be specific for the cytokine IL-6 (Yamasaki et al. 1988). Therefore, it was surprising that the IL-6 family cytokine CNTF also bound to the IL-6R and induced sig-

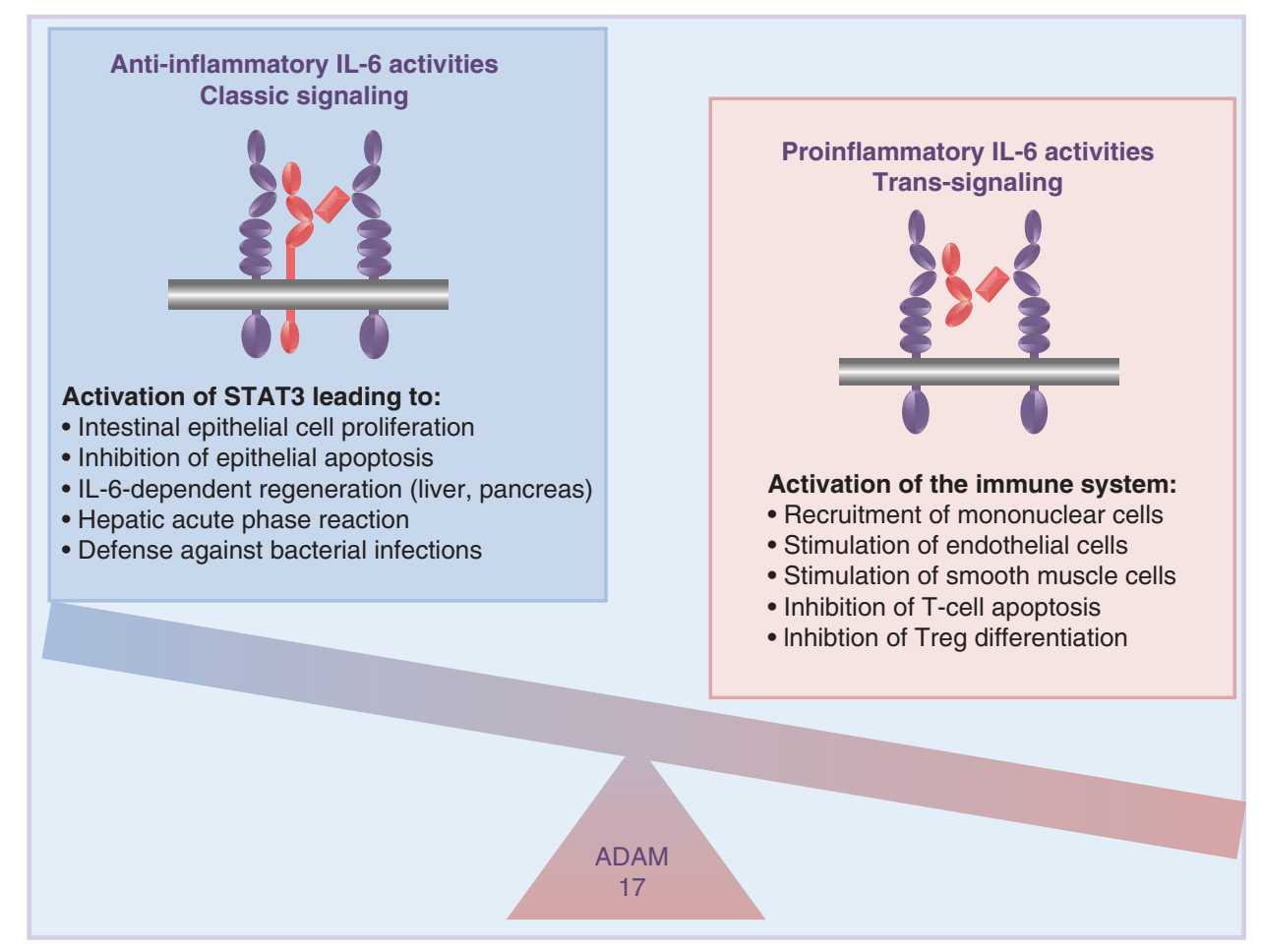

Figure 4. Pro- and anti-inflammatory activities of interleukin-6 (IL-6). IL-6 classic signaling (left) via signal transducer and activator of transcription 3 (STAT3) phosphorylation leads to protective and regenerative activities, whereas IL-6 trans-signaling (right) leads to an activation of the immune system resulting in proinflammatory IL-6 activities. Treg, Regulatory T cell. 
naling. In this case, CNTF bound to the IL-6R but signaled via a receptor complex consisting of gp130 and LIF-R (Schuster et al. 2003). This was, however, not the first reported case of receptor promiscuity in the IL-6 cytokine family. It was known that the cytokine CNTF and CLC and possibly also CT-1 acted via the CNTF receptor (CNTF-R) (Garbers et al. 2012). Recently, it was reported that $\mathrm{p} 28$, the four-helical subunit of the heterodimeric cytokine IL-27, could act via the membrane-bound or sIL-6R in the absence of EBI. Interestingly, when acting via the IL-6R, p28 formed a signaling complex of a homodimeric gp130, whereas, when acting via EBI3, p28 signaled via a heterodimeric receptor complex consisting of gp130 and WSX-1 (Garbers et al. 2013). This might have important functional consequences because a homodimeric complex of gp130 preferentially activates STAT3, whereas the heterodimeric complex of gp130 and WSX-1 rather activates STAT1, leading to a different physiologic outcome (Pflanz et al. 2004).

\section{VIRAL IL-6 FROM HUMAN HERPES VIRUS 8}

In the late 1990s, a gene of the Kaposi sarcoma virus, also called human herpes virus 8 (HHV8) was discovered, which coded for a protein that shared 25\% sequence identity with human IL-6 (Parravicini et al. 1997). It was shown that viral IL-6 (vIL-6) activated gp130 even in the absence of the IL-6R, leading to activation of the JAK/ STAT signaling pathway (Molden et al. 1997). Furthermore, it was shown that vIL-6 directly bound to and stimulated gp130, leading to the persistent proliferation of cells, which were dependent on the IL-6/sIL-6R complex, indicating that vIL-6 mimicked IL-6 trans-signaling. Consequently, the biologic activity of vIL-6 could be blocked by sgp130Fc (Mullberg et al. 2000). The direct binding of vIL-6 to gp 130 without the assistance of the IL-6R was shown by the crystal structure of the complex of gp 130 and vIL-6 (Chow et al. 2001). A comparison with the structure of the complex of IL-6, IL6R, and gp130 (Boulanger et al. 2003) shows that vIL-6 directly binds to gp130 in a similar molecular set-up as the IL-6/sIL-6R complex binds to gp 130 .
HHV-8 is associated with B-lymphoproliferative disorders, such as multicentric Castleman disease. Transgenic mice expressing serum levels of vIL-6 comparable to HHV8-infected patients spontaneously developed key features of human plasma cell-type multicentric Castleman disease (Suthaus et al. 2012). Interestingly, this disease pattern only developed in the presence of endogenous IL-6, whereas vIL-6 transgenic mice on an IL- $6^{-/-}$genetic background showed no phenotype. These results indicated that vIL-6 induced Castleman disease only in the presence of endogenous IL- 6 and it explained why in HHV8-infected patients with Castleman disease the IL-6R neutralizing antibody tocilizumab showed a therapeutic benefit although vIL-6 is not neutralized by this antibody (Nishimoto et al.2000). These results demonstrate that HHV8 mimicked the IL-6 trans-signaling paradigm and that systemic induction of IL- 6 transsignaling might have pathophysiologic consequences (Suthaus et al. 2011).

\section{THE IL-6 BUFFER IN THE BLOOD}

The levels of IL- 6 in the blood of healthy individuals are in the range of $1-5 \mathrm{pg} / \mathrm{mL}$. IL- 6 levels increase several thousand-fold during inflammatory states and can even reach levels of several $\mu \mathrm{g} / \mathrm{mL}$ under lethal septic conditions. Levels of sIL-6R were found to be in the range of $40-75 \mathrm{ng} / \mathrm{mL}$ and sgp130 levels are approximately 250-400 ng/mL (Rose-John 2015). IL6 secreted by cells will bind in the blood to the sIL-6R with an affinity of $1 \mathrm{~nm}$ and the complex of IL-6 and sIL-6R will bind to sgp130 with an affinity of $10 \mathrm{pm}$, leading to neutralization of IL6 activity. Thus, sIL-6R and sgp130 in the blood can form a buffer for IL-6. We hypothesized that this is the mechanism by which the body is protected from overstimulation by IL- 6 trans-signaling, because all cells of the body express gp130 and could be stimulated by the IL-6/ sIL-6R complex (Schaper and Rose-John 2015).

A single nucleotide polymorphism (SNP) has been identified in the human IL-6R gene, which alters Asp358 into Ala358. Asp358 is directly adjacent to the proposed proteolytic cleavage site of the IL-6R (Mullberg et al. 
S. Rose-John

1994). Consequently, shedding of the Ala358 carrying IL-6R protein by the protease ADAM17 is more efficient and levels of sIL-6R are significantly higher in homozygous individuals (Garbers et al. 2014). Remarkably, individuals with the Ala358 variant IL-6R are less susceptible to cardiovascular and arthritic diseases (Ferreira et al. 2013). This might be explained by the higher capacity of the sIL-6R/sgp130 buffer in the blood of these individuals, caused by the higher sIL-6R levels. Moreover, these data demonstrate the relevance of sIL-6R levels for the pathophysiology of inflammatory diseases.

\section{TRANS-SIGNALING AS A SPECIFICITY OVERRIDING EMERGENCY REACTION}

All cells in the body express the gp130 receptor subunit but not a single natural cytokine of the IL-6 family (with the exception of vIL-6) stimulates gp130 without the help of an additional receptor subunit (Fig. 2). The complex of IL-6 and sIL-6R, however, binds to and stimulates membrane-bound gp130. This might be the reason for the existence of the IL- 6 buffer in the blood (see above). Signal transduction via the gp130 homodimer and the heterodimer of gp130 and LIF-R or OSM-R are not identical but very similar and are mainly driven by the activation of the JAK/STAT pathway (Hermanns 2015). Stimulation of membrane-bound gp130 by the IL-6/sIL-6R complex (in the absence of IL-11R, CNTF-R, LIF-R, or OSM-R) can therefore also be seen as an overriding reaction, which could fulfill functions of all other IL-6 family cytokines (Fig. 5). ADAM17 activity, which leads to the generation of the sIL-6R, is low under normal conditions but is strongly increased in inflammatory states and in cancer (Scheller et al. 2011). Consequently, levels of sIL-6R are increased under inflammatory conditions (Rabe et al. 2008; Nowell et al. 2009; Braun et al. 2016). IL-27 may represent an exception to this because signaling via WSX-1 is mainly characterized by STAT1 activation, whereas gp130 signaling is typically dominated

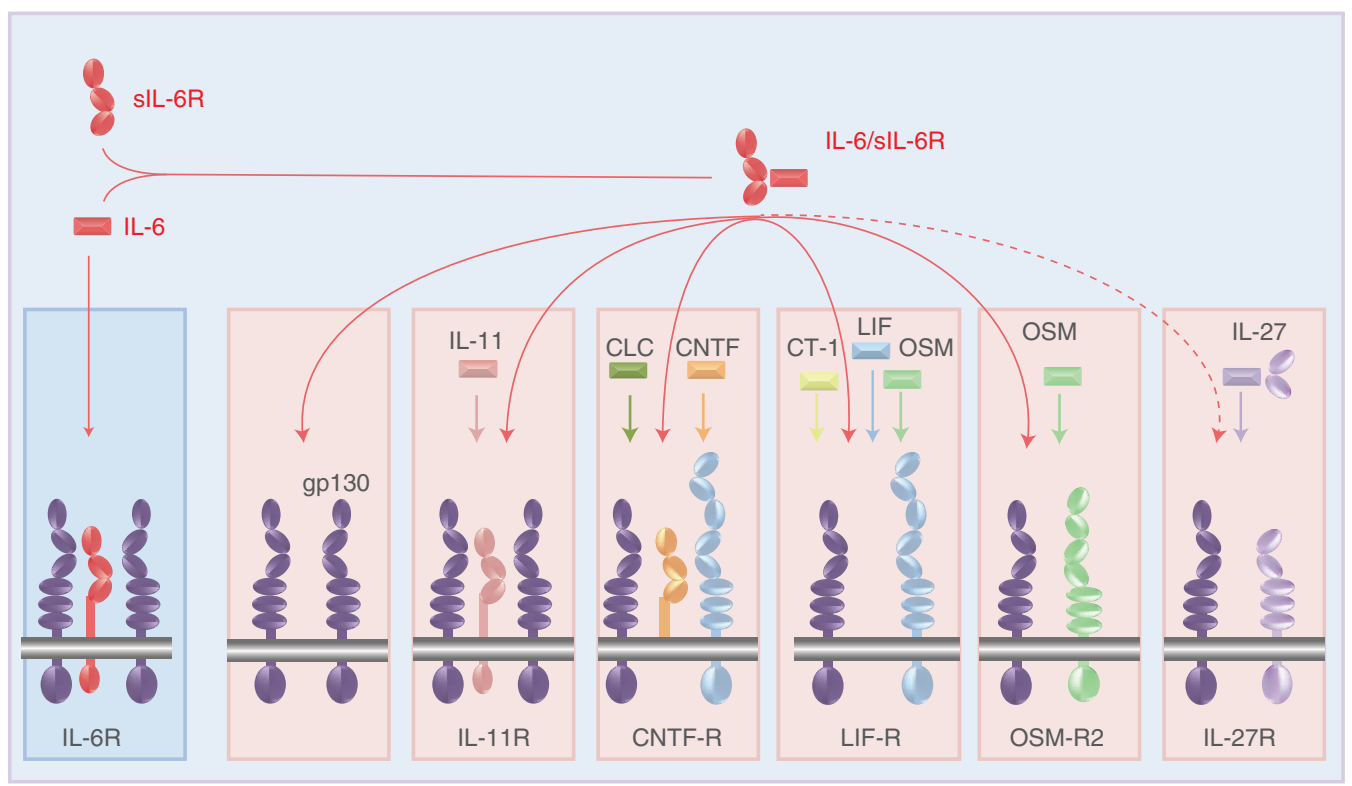

Figure 5. General gp130 activation by the interleukin-6 (IL-6)/soluble IL-6 receptor (sIL-6R) complex. Because all depicted receptor complexes of IL-6 family cytokines contain at least one molecule of gp130, the IL-6/sIL-6R complex can substitute for the activity of all depicted IL- 6 family cytokines leading to signal transducer and activator of transcription 3 (STAT3) activation. CLC, Cardiotrophin-like cytokine; CNTF, ciliary neurotrophic factor; LIF, leukemia inhibitory factor; OSM, oncostatin M. 
by STAT3 signaling. In this respect, it is interesting that the four-helical subunit p28 is involved in both gp130/WSX-1 and gp130/ gp130 signaling (see above).

\section{TRANS-SIGNALING FOR OTHER CYTOKINES?}

An interesting question is whether other IL-6 family cytokines also use trans-signaling. As is evident from Fig. 2, only cytokines that bind to a ligand-binding receptor (e.g., IL-6, IL-11, CNTF, and CLC) can theoretically perform trans-signaling, provided the respective receptor also exists in a soluble form. For IL-11, it was recently shown that the metalloprotease ADAM10 but not ADAM17 cleaves membrane-bound IL-11R, thereby generating a soluble IL-11R (sIL-11R). IL-11 bound to the sIL$11 \mathrm{R}$ could stimulate cells, which only expressed gp130 but no IL-11R. Furthermore, it was shown that IL-11 trans-signaling could be blocked by the sgp130Fc protein. Finally, evidence for the existence of sIL-11R in healthy individuals was provided (Lokau et al. 2016).

The CNTF-R is a glycosylphosphatidylinositol-anchored membrane protein and can be released from the cell membrane by phosphatidylinositol-specific phospholipase C (Davis et al. 1993). A soluble form of the CNTF-R ( $\mathrm{SCNTF}-\mathrm{R}$ ) was released by muscle tissue in response to denervation and the combination of CNTF and sCNTF-R (but not CNTF or sCNTF$\mathrm{R}$ alone) stimulated cells expressing gp130 and LIF-R but no CNTF-R leading to autophosphorylation of the LIF-R and transcription of the known CNTF target gene tis11.

These data clearly indicate that IL-11 and CNTF can stimulate cells via trans-signaling. This was further corroborated by experiments with recombinant fusion proteins of IL-11 and sIL-11R (Pflanz et al. 1999) or CNTF and sCNTF-R (Marz et al. 2002). Both fusion proteins, designed after the fusion protein hyperIL-6 (Fischer et al. 1997), were fully active on cells expressing gp130 (in the case of hyper-IL11) or gp130 and LIF-R (in the case of hyperCNTF) but not IL-11R of CNTF-R. Stimulation of the cells with fusion proteins led to
STAT3 activation and to the proliferation of murine pre-B cells (Pflanz et al. 1999; Marz et al. 2002).

In addition, other cytokines such as IL-2 and IL-15 act via ligand-binding receptor subunits (IL-2R $\alpha$, IL-15R $\alpha$ ) and the signaling receptor subunits IL-2R $\beta$ and IL-2R $\gamma$ (Waldmann 2006). An IL-15/sIL-15R fusion protein has been shown to strongly stimulate target cells expressing the IL-2R $\beta$ and IL-2R $\gamma$ receptor subunits (Desbois et al. 2016), and a soluble IL$15 \mathrm{R} \alpha$ protein has been shown to be generated by a cellular metalloprotease (Mortier et al. 2004). A soluble form of the IL-2R $\alpha$ (sIL$2 \mathrm{R} \alpha$ ) is produced by proteolysis and the levels of sIL-2R $\alpha$ are elevated in the blood of cancer patients. Furthermore, the sIL-2R $\alpha$ enhanced the biologic activity of IL-2 on several target cells (Yang et al. 2011). These data indicate that IL-2 and IL-15 can act via trans-signaling, although little is known yet about the functional importance of this pathway. Theoretically, all cytokines or growth factors could also act via trans-signaling provided they bind to a nonsignaling receptor subunit.

\section{MUTATIONS IN IL-6 FAMILY CYTOKINES AND THEIR RECEPTORS}

The physiologic functions of cytokines can often be deduced from natural mutations or from genetically engineered gene-deficient animals. Although IL-6 family cytokines often can compensate for the loss of one or more cytokines, there are phenotypes in animals with gene deficiency or with mutations in cytokine or cytokine receptor genes, which can apparently not be compensated for by other cytokines of the same family.

IL-6-deficient mice are phenotypically normal but they show an impaired hepatic acute phase response and were significantly more susceptible to bacterial infection (Kopf et al. 1994). Moreover, $\mathrm{Il}^{-/-}$mice had difficulties regenerating the liver on hepatectomy (Cressman et al. 1996).

Although $I l 11 r^{-/-}$mice develop normally and show undisturbed hematopoiesis (Nandurkar et al. 1997), mutations in the human IL11R 
gene led to a severe loss of function of the receptor and caused a craniosynostosis syndrome (Keupp et al. 2013). Female $I l 11 r^{-/-}$mice are infertile because of defective decidualization (Robb et al. 1998).

Although animals with a loss of a functional CNTF gene show only a very mild phenotype (Masu et al. 1993), mice with a deficiency in CNTF-R are unable to initiate feeding and die shortly after birth. Moreover, these mice show a dramatic loss of motor neurons (DeChiara et al. 1995). These data indicated at the time that an additional ligand for the CNTF-R should exist. This additional ligand was later identified as CLC (Elson et al. 2000). As described above, CLC acts via the CNTF-R (Fig. 2). Mutations in CLC, which result in loss of CNTF-R binding, caused cold-induced sweating syndrome. These patients sweat in the cold but are unable to sweat in hot weather (Rousseau et al. 2006).

Animals with a gene disruption in the LIF gene have been generated. These animals were phenotypically normal but they had a defect in implantation of the developing embryo. Female Lif $^{-1}$ mice are fertile but they could not implant and failed to develop their blastocysts. Nevertheless, the blastocysts are viable and can be transferred to wild-type recipients in which they normally develop to term (Stewart et al. 1992).

Mice with a gp130-sensitizing mutation have been generated by replacing the membrane proximal cytoplasmic tyrosine at position 757 of gp130 with the amino acid phenylalanine (Ernst and Jenkins 2004). This membrane proximal cytoplasmic tyrosine of gp130 is needed for negative feedback regulation of gp130 signaling by SOCS3. Consequently, the gp130-sensitized mice show a twofold higher STAT3 activation on a given gp130 stimulus as compared with wild-type mice (Nowell et al. 2009). These gp130-sensitized mice spontaneously developed gastric tumors (Judd et al. 2004) and lung emphysema (Brooks et al. 2016). Moreover, these mice were more sensitive than wild-type mice in a lipopolysaccharide (LPS)-induced sepsis model (Greenhill et al. 2011). Naturally occurring somatic mutations in human gp130, which led to ligand-indepen- dent constitutive gp130 activation, have been described in $60 \%$ of inflammatory hepatocellular adenomas (Rebouissou et al. 2009), demonstrating the importance of gp130 signaling in liver pathophysiology.

\section{CONCLUDING REMARKS}

IL-6 family cytokines are four-helical proteins and they have been grouped into a common family because of their common use of the gp130 receptor subunit. As outlined above, this strict definition does, however, not fully apply to family members such as IL-31 and IL-35. Signal transduction of IL-6 family cytokines is very similar and is dominated by STAT3 activation. The only exception is IL-27, which predominantly signals via activated STAT1.

Levels of IL-6 are very low under normal conditions, but these levels can raise many thousand-fold in inflammatory states. Autoimmune diseases such as rheumatoid arthritis are characterized by elevated IL- 6 levels, and neutralization of IL- 6 activity by the IL-6R-specific monoclonal antibody tocilizumab as a treatment of autoimmune disease has been approved in more than 100 countries. Interestingly, neutralization of IL-6 activity is at least as efficient in rheumatoid arthritis patients as neutralization of tumor necrosis factor $\alpha$.

IL-6 (and possibly also other members of the IL-6 family cytokines) apparently has proand anti-inflammatory activities. Proinflammatory activities of IL- 6 are mediated by IL-6 trans-signaling via the sIL-6R, whereas protective and anti-inflammatory activities of IL- 6 are mainly executed via the membrane-bound IL6R (classic signaling). Because IL-6 trans-signaling can be blocked by the sgp $130 \mathrm{Fc}$ protein without affecting classic signaling, future IL-6based therapies might use a specific blockade of IL-6 trans-signaling rather than a global blockade of all IL-6 activities.

\section{ACKNOWLEDGMENTS}

The work described in this review is supported by grants from the Deutsche Forschungsgemeinschaft, Bonn, Germany (SFB 841, project 
C1; SFB 877, project A1 and the Cluster of Excellence "Inflammation at Interfaces"). S.R.-J. is an inventor of patents owned by CONARIS Research Institute, which develops the sgp130Fc protein together with Ferring Pharmaceuticals and he has stock ownership in CONARIS.

\section{REFERENCES}

${ }^{*}$ Reference is also in this collection.

Abdel-Meguid SS, Shieh HS, Smith WW, Dayringer HE, Violand BN, Bentle LA. 1987. Three-dimensional structure of a genetically engineered variant of porcine growth hormone. Proc Natl Acad Sci 84: 6434-6437.

Aparicio-Siegmund S, Garbers C. 2015. The biology of interleukin-27 reveals unique pro- and anti-inflammatory functions in immunity. Cytokine Growth Factor Rev 26: 579-586.

Atreya R, Mudter J, Finotto S, Mullberg J, Jostock T, Wirtz S, Schutz M, Bartsch B, Holtmann M, Becker C, et al. 2000. Blockade of interleukin 6 trans signaling suppresses Tcell resistance against apoptosis in chronic intestinal inflammation: Evidence in Crohn's disease and experimental colitis in vivo. Nat Med 6: 583-588.

Audet J, Miller CL, Rose-John S, Piret JM, Eaves CJ. 2001. Distinct role of gp130 activation in promoting selfrenewal divisions by mitogenically stimulated murine hematopoietic stem cells. Proc Natl Acad Sci 98: 17571762.

Barkhausen T, Tschernig T, Rosenstiel P, van Griensven M, Vonberg RP, Dorsch M, Mueller-Heine A, Chalaris A, Scheller J, Rose-John S, et al. 2011. Selective blockade of interleukin-6 trans-signaling improves survival in a murine polymicrobial sepsis model. Crit Care Med 39: 1407-1413.

Bazan JF. 1990. Haemopoietic receptors and helical cytokines. Immunol Today 11: 350-354.

Bazan JF. 1992. Unraveling the structure of IL-2. Science 257: 410-413.

Boulanger MJ, Chow DC, Brevnova EE, Garcia KC. 2003. Hexameric structure and assembly of the interleukin6/IL-6 $\alpha$-receptor/gp130 complex. Science 300: $2101-$ 2104.

Brakenhoff JP, de Groot ER, Evers RF, Pannekoek H, Aarden LA. 1987. Molecular cloning and expression of hybridoma growth factor in Escherichia coli. J Immunol 139: 4116-4121.

Brakenhoff JP, Hart M, De Groot ER, Di Padova F, Aarden LA. 1990. Structure-function analysis of human IL-6. Epitope mapping of neutralizing monoclonal antibodies with amino- and carboxyl-terminal deletion mutants. $J$ Immunol 145: 561-568.

Braun GS, Nagayama Y, Maruta Y, Heymann F, van Roeyen CR, Klinkhammer BM, Boor P, Villa L, Salant DJ, Raffetseder U, et al. 2016. IL-6 trans-signaling drives murine crescentic GN. J Am Soc Nephrol 27: 132-142.

Brooks GD, McLeod L, Alhayyani S, Miller A, Russell PA, Ferlin W, Rose-John S, Ruwanpura S, Jenkins BJ. 2016.
IL6 trans-signaling promotes KRAS-driven lung carcinogenesis. Cancer Res 76: 866-876.

Calabrese LH, Rose-John S. 2014. IL-6 biology: Implications for clinical targeting in rheumatic disease. Nat Rev Rheumatol 10: 720-727.

Chalaris A, Rabe B, Paliga K, Lange H, Laskay T, Fielding CA, Jones SA, Rose-John S, Scheller J. 2007. Apoptosis is a natural stimulus of IL6R shedding and contributes to the proinflammatory trans-signaling function of neutrophils. Blood 110: 1748-1755.

Chow D, He X, Snow AL, Rose-John S, Garcia KC. 2001. Structure of an extracellular gp130 cytokine receptor signaling complex. Science 291: 2150-2155.

Cressman DE, Greenbaum LE, DeAngelis RA, Ciliberto G, Furth EE, Poli V, Taub R. 1996. Liver failure and defective hepatocyte regeneration in interleukin-6-deficient mice. Science 274: 1379-1383.

Davis S, Aldrich TH, Ip NY, Stahl N, Scherer S, Farruggella T, DiStefano PS, Curtis R, Panayotatos N, Gascan H, et al. 1993. Released form of CNTF receptor $\alpha$ component as a soluble mediator of CNTF responses. Science 259: 17361739.

DeChiara TM, Vejsada R, Poueymirou WT, Acheson A, Suri C, Conover JC, Friedman B, McClain J, Pan L, Stahl N, et al. 1995. Mice lacking the CNTF receptor, unlike mice lacking CNTF, exhibit profound motor neuron deficits at birth. Cell 83: 313-322.

Desbois M, Le Vu P, Coutzac C, Marcheteau E, Beal C, Terme M, Gey A, Morisseau S, Teppaz G, Boselli L, et al. 2016. IL-15 trans-signaling with the superagonist RLI promotes effector/memory $\mathrm{CD}^{+} \mathrm{T}$ cell responses and enhances antitumor activity of PD- 1 antagonists. J Immunol 197: 168-178.

Dillon SR, Sprecher C, Hammond A, Bilsborough J, Rosenfeld-Franklin M, Presnell SR, Haugen HS, Maurer M, Harder B, Johnston J, et al. 2004. Interleukin 31, a cytokine produced by activated $\mathrm{T}$ cells, induces dermatitis in mice. Nat Immunol 5: 752-760.

Doganci A, Eigenbrod T, Krug N, De Sanctis GT, Hausding M, Erpenbeck VJ, Haddad el B, Lehr HA, Schmitt E, Bopp T, et al. 2005. The IL-6R $\alpha$ chain controls lung $\mathrm{CD} 4{ }^{+} \mathrm{CD} 25^{+}$Treg development and function during allergic airway inflammation in vivo. J Clin Invest 115: 313-325.

Egwuagu CE, Yu CR, Sun L, Wang R. 2015. Interleukin 35: Critical regulator of immunity and lymphocyte-mediated diseases. Cytokine Growth Factor Rev 26: 587-593.

Elson GC, Lelievre E, Guillet C, Chevalier S, Plun-Favreau H, Froger J, Suard I, de Coignac AB, Delneste Y, Bonnefoy JY, et al. 2000. CLF associates with CLC to form a functional heteromeric ligand for the CNTF receptor complex. Nat Neurosci 3: 867-872.

Ernst M, Jenkins BJ. 2004. Acquiring signalling specificity from the cytokine receptor gp130. Trends Genet 20: 2332.

Febbraio MA, Rose-John S, Pedersen BK. 2010. Is interleukin-6 receptor blockade the Holy Grail for inflammatory diseases? Clin Pharmacol Ther 87: 396-398.

Ferreira RC, Freitag DF, Cutler AJ, Howson JM, Rainbow DB, Smyth DJ, Kaptoge S, Clarke P, Boreham C, Coulson RM, et al. 2013. Functional IL6R 358Ala allele impairs 
S. Rose-John

classical IL-6 receptor signaling and influences risk of diverse inflammatory diseases. PLoS Genet 9: e1003444.

Fischer M, Goldschmitt J, Peschel C, Brakenhoff JP, Kallen KJ, Wollmer A, Grotzinger J, Rose-John S. 1997. A bioactive designer cytokine for human hematopoietic progenitor cell expansion. Nat Biotechnol 15: 142-145.

Gabay C, Emery P, van Vollenhoven R, Dikranian A, Alten R, Pavelka K, Klearman M, Musselman D, Agarwal S, Green J, et al. 2013. Tocilizumab monotherapy versus adalimumab monotherapy for treatment of rheumatoid arthritis (ADACTA): A randomised, double-blind, controlled phase 4 trial. Lancet 381: 1541-1550.

Galun E, Zeira E, Pappo O, Peters M, Rose-John S. 2000. Liver regeneration induced by a designer human IL-6/ sIL-6R fusion protein reverses severe hepatocellular injury. FASEB J 14: 1979-1987.

Gandhi NA, Bennett BL, Graham NM, Pirozzi G, Stahl N, Yancopoulos GD. 2016. Targeting key proximal drivers of type 2 inflammation in disease. Nat Rev Drug Discov 15: $35-50$.

Garbers C, Hermanns HM, Schaper F, Muller-Newen G, Grotzinger J, Rose-John S, Scheller J. 2012. Plasticity and cross-talk of interleukin 6-type cytokines. Cytokine Growth Factor Rev 23: 85-97.

Garbers C, Spudy B, Aparicio-Siegmund S, Waetzig GH, Sommer J, Holscher C, Rose-John S, Grotzinger J, Lorenzen I, Scheller J. 2013. An interleukin-6 receptor-dependent molecular switch mediates signal transduction of the IL-27 cytokine subunit p28 (IL-30) via a gp130 protein receptor homodimer. J Biol Chem 288: 43464354.

Garbers C, Monhasery N, Aparicio-Siegmund S, Lokau J, Baran P, Nowell MA, Jones SA, Rose-John S, Scheller J. 2014. The interleukin-6 receptor Asp358Ala single nucleotide polymorphism rs2228145 confers increased proteolytic conversion rates by ADAM proteases. Biochim Biophys Acta 1842: 1485-1494.

Gauldie J, Richards C, Harnish D, Lansdorp P, Baumann H. 1987. Interferon $\beta 2 / B$-cell stimulatory factor type 2 shares identity with monocyte-derived hepatocyte-stimulating factor and regulates the major acute phase protein response in liver cells. Proc Natl Acad Sci 84: 7251-7255.

Gearing DP, Gough NM, King JA, Hilton DJ, Nicola NA, Simpson RJ, Nice EC, Kelso A, Metcalf D. 1987. Molecular cloning and expression of CDNA encoding a murine myeloid leukaemia inhibitory factor (LIF). EMBO J 6: 3995-4002.

Gearing DP, Thut CJ, VandeBos T, Gimpel SD, Delaney PB, King J, Price V, Cosman D, Beckmann MP. 1991. Leukemia inhibitory factor receptor is structurally related to the IL-6 signal transducer, gp130. EMBO J 10: 28392848.

Gearing DP, Comeau MR, Friend DJ, Gimpel SD, Thut CJ, McGourty J, Brasher KK, King JA, Gillis S, Mosley B, et al. 1992. The IL-6 signal transducer, gp 130: An oncostatin M receptor and affinity converter for the LIF receptor. Science 255: 1434-1437.

Greenhill CJ, Rose-John S, Lissilaa R, Ferlin W, Ernst M, Hertzog PJ, Mansell A, Jenkins BJ. 2011. IL-6 trans-signaling modulates TLR4-dependent inflammatory responses via STAT3. J Immunol 186: 1199-1208.
Grivennikov S, Karin E, Terzic J, Mucida D, Yu GY, Vallabhapurapu S, Scheller J, Rose-John S, Cheroutre H, Eckmann L, et al. 2009. IL-6 and Stat 3 are required for survival of intestinal epithelial cells and development of colitis-associated cancer. Cancer Cell 15: 103-113.

Haegeman G, Content J, Volckaert G, Derynck R, Tavernier J, Fiers W. 1986. Structural analysis of the sequence coding for an inducible $26-\mathrm{kD}$ a protein in human fibroblasts. Eur J Biochem 159: 625-632.

Hermanns HM. 2015. Oncostatin M and interleukin-31: Cytokines, receptors, signal transduction and physiology. Cytokine Growth Factor Rev 26: 545-558.

Hibi M, Murakami M, Saito M, Hirano T, Taga T, Kishimoto T. 1990. Molecular cloning and expression of an IL-6 signal transducer, gp130. Cell 63: 1149-1157.

Hirano T, Yasukawa K, Harada H, Taga T, Watanabe Y, Matsuda T, Kashiwamura S, Nakajima K, Koyama K, Iwamatsu A, et al. 1986. Complementary DNA for a novel human interleukin (BSF-2) that induces B lymphocytes to produce immunoglobulin. Nature 324: 73-76.

Hirano T, Taga T, Yamasaki K, Matsuda T, Yasukawa K, Hirata Y, Yawata H, Tanabe O, Akira S, Kishimoto T. 1989. Molecular cloning of the cDNAs for interleukin-6/B cell stimulatory factor 2 and its receptor. Ann NY Acad Sci 557: 167-178; discussion 178-180.

Hoge J, Yan I, Janner N, Schumacher V, Chalaris A, Steinmetz OM, Engel DR, Scheller J, Rose-John S, Mittrucker HW. 2013. IL-6 controls the innate immune response against Listeria monocytogenes via classical IL-6 signaling. J Immunol 190: 703-711.

Humphrey RK, Beattie GM, Lopez AD, Bucay N, King CC, Firpo MT, Rose-John S, Hayek A. 2004. Maintenance of pluripotency in human embryonic stem cells is STAT3 independent. Stem Cells 22: 522-530.

Jones SA, Rose-John S. 2002. The role of soluble receptors in cytokine biology: The agonistic properties of the sIL-6R/ IL-6 complex. Biochim Biophys Acta 1592: 251-263.

Jones SA, Scheller J, Rose-John S. 2011. Therapeutic strategies for the clinical blockade of IL-6/gp130 signaling. J Clin Invest 121: 3375-3383.

Jostock T, Mullberg J, Ozbek S, Atreya R, Blinn G, Voltz N, Fischer M, Neurath MF, Rose-John S. 2001. Soluble gp130 is the natural inhibitor of soluble interleukin-6 receptor transsignaling responses. Eur J Biochem 268: $160-167$.

Judd LM, Alderman BM, Howlett M, Shulkes A, Dow C, Moverley J, Grail D, Jenkins BJ, Ernst M, Giraud AS. 2004. Gastric cancer development in mice lacking the SHP2 binding site on the IL-6 family co-receptor gp130. Gastroenterology 126: 196-207.

Keupp K, Li Y, Vargel I, Hoischen A, Richardson R, Neveling K, Alanay Y, Uz E, Elcioglu N, Rachwalski M, et al. 2013. Mutations in the interleukin receptor IL11RA cause autosomal recessive Crouzon-like craniosynostosis. $\mathrm{Mol}$ Genet Genomic Med 1: 223-237.

Klouche M, Bhakdi S, Hemmes M, Rose-John S. 1999. Novel path to activation of vascular smooth muscle cells: Upregulation of gp130 creates an autocrine activation loop by IL-6 and its soluble receptor. J Immunol 163: 45834589.

Kopf M, Baumann H, Freer G, Freudenberg M, Lamers M, Kishimoto T, Zinkernagel R, Bluethmann H, Kohler G. 
1994. Impaired immune and acute-phase responses in interleukin-6-deficient mice. Nature 368: 339-342.

Kraakman MJ, Kammoun HL, Allen TL, Deswaerte V, Henstridge DC, Estevez E, Matthews VB, Neill B, White DA, Murphy AJ, et al. 2015. Blocking IL-6 trans-signaling prevents high-fat diet-induced adipose tissue macrophage recruitment but does not improve insulin resistance. Cell Metab 21: 403-416.

Ladel CH, Blum C, Dreher A, Reifenberg K, Kopf M, Kaufmann SH. 1997. Lethal tuberculosis in interleukin-6-deficient mutant mice. Infect Immun 65: 4843-4849.

Lesina M, Kurkowski MU, Ludes K, Rose-John S, Treiber M, Kloppel G, Yoshimura A, Reindl W, Sipos B, Akira S, et al. 2011. Stat3/Socs3 activation by IL-6 transsignaling promotes progression of pancreatic intraepithelial neoplasia and development of pancreatic cancer. Cancer Cell 19: 456-469.

Levy DE, Darnell JEJr. 2002. STATs: Transcriptional control and biological impact. Nat Rev Mol Cell Biol 3: 651-662.

Lin LF, Mismer D, Lile JD, Armes LG, Butler ET III, Vannice JL, Collins F. 1989. Purification, cloning, and expression of ciliary neurotrophic factor (CNTF). Science 246: $1023-1025$.

Lo CW, Chen MW, Hsiao M, Wang S, Chen CA, Hsiao SM, Chang JS, Lai TC, Rose-John S, Kuo ML, et al. 2011. IL-6 trans-signaling in formation and progression of malignant ascites in ovarian cancer. Cancer Res 71: 424-434.

Lokau J, Nitz R, Agthe M, Monhasery N, Aparicio-Siegmund S, Schumacher N, Wolf J, Moller-Hackbarth K, Waetzig GH, Grotzinger J, et al. 2016. Proteolytic cleavage governs interleukin-11 trans-signaling. Cell Rep 14: 1761-1773.

Luig M, Kluger MA, Goerke B, Meyer M, Nosko A, Yan I, Scheller J, Mittrucker HW, Rose-John S, Stahl RA, et al. 2015. Inflammation-induced IL-6 functions as a natural brake on macrophages and limits GN. J Am Soc Nephrol 26: $1597-1607$.

Lupardus PJ, Skiniotis G, Rice AJ, Thomas C, Fischer S, Walz T, Garcia KC. 2011. Structural snapshots of full-length Jak1, a transmembrane gp130/IL-6/IL-6R $\alpha$ cytokine receptor complex, and the receptor-Jak1 holocomplex. Structure 19: 45-55.

Lust JA, Donovan KA, Kline MP, Greipp PR, Kyle RA, Maihle NJ. 1992. Isolation of an mRNA encoding a soluble form of the human interleukin-6 receptor. Cytokine 4: 96-100.

Lutticken C, Wegenka UM, Yuan J, Buschmann J, Schindler C, Ziemiecki A, Harpur AG, Wilks AF, Yasukawa K, Taga T, et al. 1994. Association of transcription factor APRF and protein kinase Jak1 with the interleukin-6 signal transducer gp130. Science 263: 89-92.

Mackiewicz A, Schooltink H, Heinrich PC, Rose-John S. 1992. Complex of soluble human IL-6-receptor/IL-6 up-regulates expression of acute-phase proteins. J Immunol 149: 2021-2027.

Malik N, Kallestad JC, Gunderson NL, Austin SD, Neubauer MG, Ochs V, Marquardt H, Zarling JM, Shoyab M, Wei CM, et al. 1989. Molecular cloning, sequence analysis, and functional expression of a novel growth regulator, oncostatin M. Mol Cell Biol 9: 2847-2853.

Marz P, Ozbek S, Fischer M, Voltz N, Otten U, Rose-John S. 2002. Differential response of neuronal cells to a fusion protein of ciliary neurotrophic factor/soluble CNTF-receptor and leukemia inhibitory factor. Eur J Biochem 269: 3023-3031.

Masu Y, Wolf E, Holtmann B, Sendtner M, Brem G, Thoenen H. 1993. Disruption of the CNTF gene results in motor neuron degeneration. Nature 365: 27-32.

Matsumoto S, Hara T, Mitsuyama K, Yamamoto M, Tsuruta O, Sata M, Scheller J, Rose-John S, Kado S, Takada T. 2010. Essential roles of IL-6 trans-signaling in colonic epithelial cells, induced by the IL-6/soluble-IL-6 receptor derived from lamina propria macrophages, on the development of colitis-associated premalignant cancer in a murine model. J Immunol 184: 1543-1551.

Matthews VB, Allen TL, Risis S, Chan MH, Henstridge DC, Watson N, Zaffino LA, Babb JR, Boon J, Meikle PJ, et al. 2010. Interleukin-6-deficient mice develop hepatic inflammation and systemic insulin resistance. Diabetologia 53: $2431-2441$.

Mitsuyama K, Matsumoto S, Rose-John S, Suzuki A, Hara T, Tomiyasu N, Handa K, Tsuruta O, Funabashi H, Scheller J, et al. 2006. STAT3 activation via interleukin 6 transsignalling contributes to ileitis in SAMP1/Yit mice. Gut 55: 1263-1269.

Molden J, Chang Y, You Y, Moore PS, Goldsmith MA. 1997. A Kaposi's sarcoma-associated herpesvirus-encoded cytokine homolog (vIL-6) activates signaling through the shared gp130 receptor subunit. J Biol Chem 272: $19625-$ 19631.

Mortier E, Bernard J, Plet A, Jacques Y. 2004. Natural, proteolytic release of a soluble form of human IL-15 receptor $\alpha$-chain that behaves as a specific, high affinity IL-15 antagonist. J Immunol 173: 1681-1688.

Mosley B, De Imus C, Friend D, Boiani N, Thoma B, Park LS, Cosman D. 1996. Dual oncostatin M (OSM) receptors. Cloning and characterization of an alternative signaling subunit conferring OSM-specific receptor activation. J Biol Chem 271: 32635-32643.

Mullberg J, Schooltink H, Stoyan T, Heinrich PC, Rose-John S. 1992. Protein kinase $\mathrm{C}$ activity is rate limiting for shedding of the interleukin-6 receptor. Biochem Biophys Res Commun 189: 794-800.

Mullberg J, Schooltink H, Stoyan T, Gunther M, Graeve L, Buse G, Mackiewicz A, Heinrich PC, Rose-John S. 1993. The soluble interleukin-6 receptor is generated by shedding. Eur J Immunol 23: 473-480.

Mullberg J, Oberthur W, Lottspeich F, Mehl E, Dittrich E, Graeve L, Heinrich PC, Rose-John S. 1994. The soluble human IL-6 receptor. Mutational characterization of the proteolytic cleavage site. J Immunol 152: 4958-4968.

Mullberg J, Geib T, Jostock T, Hoischen SH, Vollmer P, Voltz N, Heinz D, Galle PR, Klouche M, Rose-John S. 2000. IL6 receptor independent stimulation of human gp130 by viral IL-6. J Immunol 164: 4672-4677.

Nandurkar HH, Robb L, Tarlinton D, Barnett L, Kontgen F, Begley CG. 1997. Adult mice with targeted mutation of the interleukin-11 receptor (IL11Ra) display normal hematopoiesis. Blood 90: 2148-2159.

Nishimoto N, Sasai M, Shima Y, Nakagawa M, Matsumoto T, Shirai T, Kishimoto T, Yoshizaki K. 2000. Improvement in Castleman's disease by humanized anti-interleukin- 6 receptor antibody therapy. Blood 95: 56-61. 
S. Rose-John

Nowell MA, Richards PJ, Horiuchi S, Yamamoto N, RoseJohn S, Topley N, Williams AS, Jones SA. 2003. Soluble IL-6 receptor governs IL-6 activity in experimental arthritis: Blockade of arthritis severity by soluble glycoprotein 130. J Immunol 171: 3202-3209.

Nowell MA, Williams AS, Carty SA, Scheller J, Hayes AJ, Jones GW, Richards PJ, Slinn S, Ernst M, Jenkins BJ, et al. 2009. Therapeutic targeting of IL-6 trans signaling counteracts STAT 3 control of experimental inflammatory arthritis. J Immunol 182: 613-622.

Oberg HH, Wesch D, Grussel S, Rose-John S, Kabelitz D. 2006. Differential expression of CD126 and CD130 mediates different STAT-3 phosphorylation in $\mathrm{CD}^{+}$ $\mathrm{CD} 25$ - and $\mathrm{CD} 25^{\text {high }}$ regulatory $\mathrm{T}$ cells. Int Immunol 18: $555-563$.

Parravicini C, Corbellino M, Paulli M, Magrini U, Lazzarino M, Moore PS, Chang Y. 1997. Expression of a virus-derived cytokine, KSHV vIL-6, in HIV-seronegative Castleman's disease. Am J Pathol 151: 1517-1522.

Paul SR, Bennett F, Calvetti JA, Kelleher K, Wood CR, O’Hara RMJr, Leary AC, Sibley B, Clark SC, Williams DA, et al. 1990. Molecular cloning of a cDNA encoding interleukin 11, a stromal cell-derived lymphopoietic and hematopoietic cytokine. Proc Natl Acad Sci 87: 75127516.

Pennica D, King KL, Shaw KJ, Luis E, Rullamas J, Luoh SM, Darbonne WC, Knutzon DS, Yen R, Chien KR, et al. 1995. Expression cloning of cardiotrophin 1, a cytokine that induces cardiac myocyte hypertrophy. Proc Natl Acad Sci 92: 1142-1146.

Pennica D, Arce V, Swanson TA, Vejsada R, Pollock RA, Armanini M, Dudley K, Phillips HS, Rosenthal A, Kato AC, et al. 1996. Cardiotrophin-1, a cytokine present in embryonic muscle, supports long-term survival of spinal motoneurons. Neuron 17: 63-74.

Peters M, Blinn G, Jostock T, Schirmacher P, Meyer zum Buschenfelde KH, Galle PR, Rose-John S. 2000. Combined interleukin 6 and soluble interleukin 6 receptor accelerates murine liver regeneration. Gastroenterology 119: $1663-1671$.

Pflanz S, Tacken I, Grotzinger J, Jacques Y, Minvielle S, Dahmen H, Heinrich PC, Muller-Newen G. 1999. A fusion protein of interleukin-11 and soluble interleukin-11 receptor acts as a superagonist on cells expressing gp130. FEBS Lett 450: 117-122.

Pflanz S, Hibbert L, Mattson J, Rosales R, Vaisberg E, Bazan JF, Phillips JH, McClanahan TK, de Waal Malefyt R, Kastelein RA. 2004. WSX-1 and glycoprotein 130 constitute a signal-transducing receptor for IL-27. J Immunol 172: 2225-2231.

Rabe B, Chalaris A, May U, Waetzig GH, Seegert D, Williams AS, Jones SA, Rose-John S, Scheller J. 2008. Transgenic blockade of interleukin 6 transsignaling abrogates inflammation. Blood 111: 1021-1028.

Rebouissou S, Amessou M, Couchy G, Poussin K, Imbeaud S, Pilati C, Izard T, Balabaud C, Bioulac-Sage P, ZucmanRossi J. 2009. Frequent in-frame somatic deletions activate gp130 in inflammatory hepatocellular tumours. $\mathrm{Na}$ ture 457: 200-204.

Richards PJ, Nowell MA, Horiuchi S, McLoughlin RM, Fielding CA, Grau S, Yamamoto N, Ehrmann M, RoseJohn S, Williams AS, et al. 2006. Functional characteri- zation of a soluble gp130 isoform and its therapeutic capacity in an experimental model of inflammatory arthritis. Arthritis Rheum 54: 1662-1672.

Robb L, Li R, Hartley L, Nandurkar HH, Koentgen F, Begley CG. 1998. Infertility in female mice lacking the receptor for interleukin 11 is due to a defective uterine response to implantation. Nat Med 4: 303-308.

Rose-John S. 2015. The soluble interleukin-6 receptor and related proteins. Best Pract Res Clin Endocrinol Metab 29: 787-797.

Rose-John S, Heinrich PC. 1994. Soluble receptors for cytokines and growth factors: Generation and biological function. Biochem J 300: 281-290.

Rose-John S, Scheller J, Schaper F. 2015. "Family reunion”A structured view on the composition of the receptor complexes of interleukin-6-type and interleukin-12type cytokines. Cytokine Growth Factor Rev 26: 471-474.

Rousseau F, Gauchat JF, McLeod JG, Chevalier S, Guillet C, Guilhot F, Cognet I, Froger J, Hahn AF, Knappskog PM, et al. 2006. Inactivation of cardiotrophin-like cytokine, a second ligand for ciliary neurotrophic factor receptor, leads to cold-induced sweating syndrome in a patient. Proc Natl Acad Sci 103: 10068-10073.

Ruwanpura SM, McLeod L, Dousha LF, Seow HJ, Alhayyani S, Tate MD, Deswaerte V, Brooks GD, Bozinovski S, MacDonald M, et al. 2016. Therapeutic targeting of the IL-6 trans-signaling/mechanistic target of rapamycin complex 1 axis in pulmonary emphysema. Am J Respir Crit Care Med doi: 10.1164/rccm.201512-2368OC.

Schaper F, Rose-John S. 2015. Interleukin-6: Biology, signaling and strategies of blockade. Cytokine Growth Factor Rev 26: 475-487.

Scheller J, Chalaris A, Garbers C, Rose-John S. 2011. ADAM17: A molecular switch to control inflammation and tissue regeneration. Trends Immunol 32: 380-387.

Schmidt-Arras D, Rose-John S. 2016. IL-6 pathway in the liver: From physiopathology to therapy. J Hepatol 64: 1403-1415.

Schuett H, Oestreich R, Waetzig GH, Annema W, Luchtefeld M, Hillmer A, Bavendiek U, von Felden J, Divchev D, Kempf T, et al. 2012. Transsignaling of interleukin-6 crucially contributes to atherosclerosis in mice. Arterioscler Thromb Vasc Biol 32: 281-290.

Schumacher N, Meyer D, Mauermann A, von der Heyde J, Wolf J, Schwarz J, Knittler K, Murphy G, Michalek M, Garbers C, et al. 2015. Shedding of endogenous interleukin- 6 receptor (IL-6R) is governed by a disintegrin and metalloproteinase (ADAM) proteases while a full-length IL-6R isoform localizes to circulating microvesicles. J Biol Chem 290: 26059-26071.

Schuster B, Kovaleva M, Sun Y, Regenhard P, Matthews V, Grotzinger J, Rose-John S, Kallen KJ. 2003. Signaling of human ciliary neurotrophic factor (CNTF) revisited. The interleukin-6 receptor can serve as an $\alpha$-receptor for CTNF. J Biol Chem 278: 9528-9535.

Selmi C, Ceribelli A, Naguwa SM, Cantarini L, Shoenfeld Y. 2015. Safety issues and concerns of new immunomodulators in rheumatology. Expert Opin Drug Saf 14: 389399.

Sodenkamp J, Waetzig GH, Scheller J, Seegert D, Grotzinger J, Rose-John S, Ehlers S, Holscher C. 2012. Therapeutic targeting of interleukin-6 trans-signaling does not affect 
the outcome of experimental tuberculosis. Immunobiology 217: 996-1004.

Spangler JB, Moraga I, Mendoza JL, Garcia KC. 2015. Insights into cytokine-receptor interactions from cytokine engineering. Anпu Rev Immunol 33: 139-167.

* Stark GR, Cheon HJ, Wang Y. 2017. Responses to cytokines and interferons that depend upon JAKs and STATs. Cold Spring Harb Perspect Biol doi: 10.1101/cshperspect. a028555.

Stewart CL, Kaspar P, Brunet LJ, Bhatt H, Gadi I, Kontgen F, Abbondanzo SJ. 1992. Blastocyst implantation depends on maternal expression of leukaemia inhibitory factor. Nature 359: 76-79.

Stockli KA, Lottspeich F, Sendtner M, Masiakowski P, Carroll P, Gotz R, Lindholm D, Thoenen H. 1989. Molecular cloning, expression and regional distribution of rat ciliary neurotrophic factor. Nature 342: 920-923.

Suthaus J, Adam N, Grotzinger J, Scheller J, Rose-John S. 2011. Viral Interleukin-6: Structure, pathophysiology and strategies of neutralization. Eur J Cell Biol 90: 495504.

Suthaus J, Stuhlmann-Laeisz C, Tompkins VS, Rosean TR, Klapper W, Tosato G, Janz S, Scheller J, Rose-John S. 2012. HHV-8-encoded viral IL-6 collaborates with mouse IL-6 in the development of multicentric Castleman disease in mice. Blood 119: 5173-5181.

Taga T, Hibi M, Hirata Y, Yamasaki K, Yasukawa K, Matsuda T, Hirano T, Kishimoto T. 1989. Interleukin-6 triggers the association of its receptor with a possible signal transducer, gp130. Cell 58: 573-581.

Tanaka T, Narazaki M, Ogata A, Kishimoto T. 2014. A new era for the treatment of inflammatory autoimmune diseases by interleukin-6 blockade strategy. Semin Immunol 26: $88-96$

The New York Academy of Sciences Conference. 1988. Regulation of the acute phase and immune responses: Interleukin-6 (ed. Sehgal PB, Grieninger G, Tosato G). The New York Academy of Sciences, New York.

Tsantikos E, Maxwell MJ, Putoczki T, Ernst M, Rose-John S, Tarlinton DM, Hibbs ML. 2013. Interleukin-6 trans-sig- naling exacerbates inflammation and renal pathology in lupus-prone mice. Arthritis Rheum 65: 2691-2702.

Viswanathan S, Benatar T, Rose-John S, Lauffenburger DA, Zandstra PW. 2002. Ligand/receptor signaling threshold (LIST) model accounts for gp130-mediated embryonic stem cell self-renewal responses to LIF and HIL-6. Stem Cells 20: 119-138.

Waldmann TA. 2006. The biology of interleukin-2 and interleukin-15: Implications for cancer therapy and vaccine design. Nat Rev Immunol 6: 595-601.

Wei LH, Chou CH, Chen MW, Rose-John S, Kuo ML, Chen SU, Yang YS. 2013. The role of IL-6 trans-signaling in vascular leakage: Implications for ovarian hyperstimulation syndrome in a murine model. J Clin Endocrinol Metab 98: E472-E484.

Wunderlich FT, Ströhle P, Könner AC, Gruber S, Tovar S, Brönneke HS, Juntti-Berggren L, Li LS, van Rooijen N, Libert C, et al. 2010. Interleukin-6 signaling in liver-parenchymal cells suppresses hepatic inflammation and improves systemic insulin action. Cell Metab 12: 237-249.

Yamasaki K, Taga T, Hirata Y, Yawata H, Kawanishi Y, Seed B, Taniguchi T, Hirano T, Kishimoto T. 1988. Cloning and expression of the human interleukin-6 (BSF-2/IFN $\beta 2$ ) receptor. Science 241: 825-828.

* Yan J, Smyth MJ, Teng MWL. 2017. IL-12 and IL-23 and their conflicting roles in cancer. Cold Spring Harb Perspect Biol doi: $10.1101 /$ cshperspect.a028530.

Yang ZZ, Grote DM, Ziesmer SC, Manske MK, Witzig TE, Novak AJ, Ansell SM. 2011. Soluble IL-2R $\alpha$ facilitates IL2-mediated immune responses and predicts reduced survival in follicular B-cell non-Hodgkin lymphoma. Blood 118: $2809-2820$.

Zhang H, Neuhofer P, Song L, Rabe B, Lesina M, Kurkowski MU, Treiber M, Wartmann T, Regner S, Thorlacius H, et al. 2013. IL-6 trans-signaling promotes pancreatitis-associated lung injury and lethality. J Clin Invest 123: 10191031.

Zilberstein A, Ruggieri R, Korn JH, Revel M. 1986. Structure and expression of $\mathrm{CDNA}$ and genes for human interferon$\beta-2$, a distinct species inducible by growth-stimulatory cytokines. EMBO J 5: 2529-2537. 


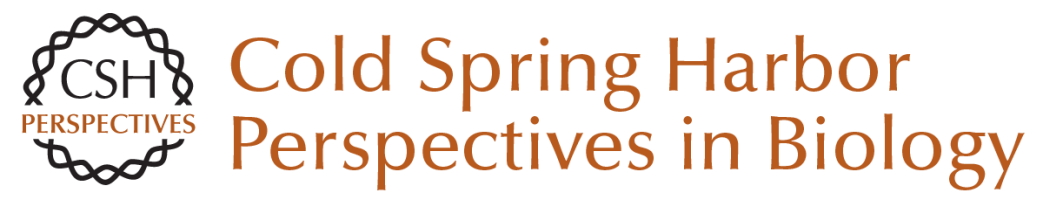

\section{Interleukin-6 Family Cytokines}

Stefan Rose-John

Cold Spring Harb Perspect Biol 2018; doi: 10.1101/cshperspect.a028415 originally published online June 15, 2017

\section{Subject Collection Cytokines}

Interleukin (IL)-33 and the IL-1 Family of Cytokines -Regulators of Inflammation and Tissue Homeostasis

Ajithkumar Vasanthakumar and Axel Kallies

Targeting IL-10 Family Cytokines for the Treatment of Human Diseases Xiaoting Wang, Kit Wong, Wenjun Ouyang, et al.

Cytokine-Mediated Regulation of CD8 T-Cell Responses During Acute and Chronic Viral Infection

Masao Hashimoto, Se Jin Im, Koichi Araki, et al.

Cytokines in Cancer Immunotherapy

Thomas A. Waldmann

The Tumor Necrosis Factor Family: Family Conventions and Private Idiosyncrasies David Wallach

The Interferon (IFN) Class of Cytokines and the IFN Regulatory Factor (IRF) Transcription Factor Family

Hideo Negishi, Tadatsugu Taniguchi and Hideyuki Yanai
Interferon $\gamma$ and Its Important Roles in Promoting and Inhibiting Spontaneous and Therapeutic Cancer Immunity

Elise Alspach, Danielle M. Lussier and Robert D. Schreiber

Inflammasome-Dependent Cytokines at the Crossroads of Health and Autoinflammatory Disease

Hanne Van Gorp, Nina Van Opdenbosch and Mohamed Lamkanfi

Innate Lymphoid Cells (ILCs): Cytokine Hubs Regulating Immunity and Tissue Homeostasis Maho Nagasawa, Hergen Spits and Xavier Romero Ros

T Helper Cell Differentiation, Heterogeneity, and

Plasticity Jinfang Zhu

Development, Diversity, and Function of Dendritic Cells in Mouse and Human

David A. Anderson III, Kenneth M. Murphy and Carlos G. Briseño

Cytokines and Long Noncoding RNAs Susan Carpenter and Katherine A. Fitzgerald

For additional articles in this collection, see http://cshperspectives.cshlp.org/cgi/collection/

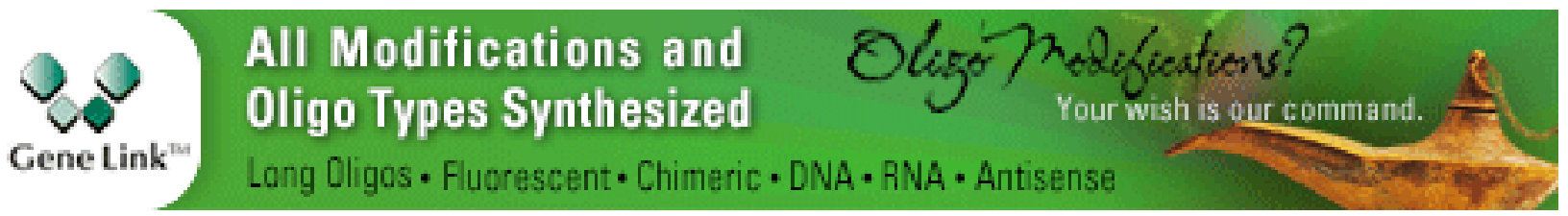

Copyright @ 2018 Cold Spring Harbor Laboratory Press; all rights reserved 
Role of the $\beta$ Common $(\beta \mathrm{c})$ Family of Cytokines in Health and Disease

Timothy R. Hercus, Winnie L. T. Kan, Sophie E. Broughton, et al.

Interleukin (IL)-12 and IL-23 and Their Conflicting Roles in Cancer Juming Yan, Mark J. Smyth and Michele W.L. Teng
Negative Regulation of Cytokine Signaling in Immunity

Akihiko Yoshimura, Minako Ito, Shunsuke Chikuma, et al.

Cancer Inflammation and Cytokines

Maria Rosaria Galdiero, Gianni Marone and Alberto Mantovani

For additional articles in this collection, see http://cshperspectives.cshlp.org/cgi/collection/

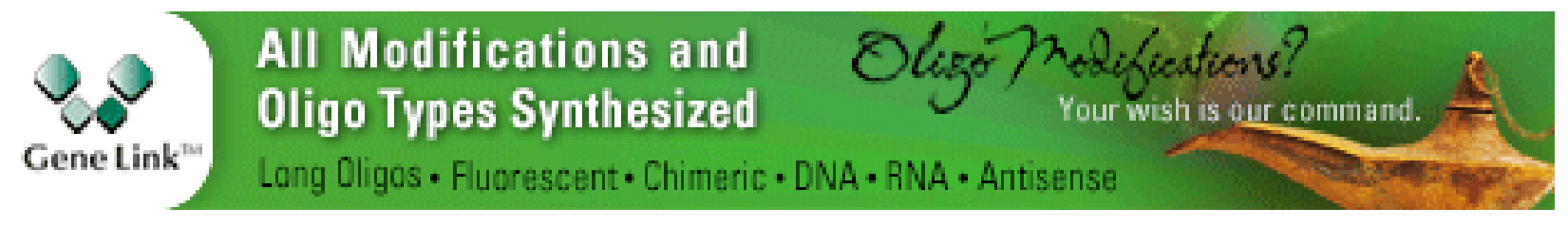

Copyright @ 2018 Cold Spring Harbor Laboratory Press; all rights reserved 